\title{
EquiLIBRIUM
}

Quarterly Journal of Economics and Economic Policy

2016 VOLUME 11 ISSUE 3, September

p-ISSN 1689-765X, e-ISSN 2353-3293

www.economic-policy.pl

Ząbkowicz, A. (2016). A Paradox of Reforming Pensions in Poland. Equilibrium. Quarterly Journal of Economics and Economic Policy, 11(3), 585-602. DOI: http://dx.doi.org/10.12775/EQUIL.2016.026

Anna Ząbkowicz*

Jagiellonian University, Poland

\section{A Paradox of Reforming Pensions in Poland}

JEL Classification: $P 16 ; B 52$

Keywords: funded pensions; pension reform; public finance

\begin{abstract}
Recent years see intense reforming of funded pensions sub-system in Poland. Actually, what are the policy objectives at which change in design introduced in 2013 (mandatory funding) and projected in 2014 (voluntary funding) is oriented? The article briefly reports what contemporary re-designing of the pension system at different stages was about, and reconstructs the objectives of reforming at each stage. It finds that interlocking streams of change aimed at two goals in fact which are i) relief to public finance ii) expanding pension funding by financial intermediaries. It argues that the two are in contradiction to each other, and this makes a paradox of pension reforming. The review of 2013-and 2014design, unexpectedly enough, results in conclusion that at present reforming is focused on pension funding revitalization, which may cause a recurring distress to public finance. Thus, the article identifies one of dilemmas of institutional-order development in Poland, which can be probably also experienced in other countries where pension funding has been introduced.
\end{abstract}

(C) Copyright Institute of Economic Research

Date of submission: April 18, 2015; date of acceptance: April 6, 2016

* Contact: anna.zabkowicz@uj.edu.pl, Uniwersytet Jagielloński, WZiKS, ul. Łojasiewicza 4, 30-348 Kraków, Poland 


\section{Introduction}

Funded pensions introduced in Poland in 1999 appear to be an issue which is intensely debated from time to time. In January 2015 the topic returned with the project of reforming pension funds created on voluntary basis. December 2013 saw a relevant change in rules that govern mandatory funding. Mandatory funding was scaled down, while voluntary funding can see „pumping-in” both of public and members' money. Understanding of the process at stake is in no proportion to the temperature of the publicity provided. Are the privately managed tiers of pension system in Poland in demise or on rise? This is an attempt to understand reforming at recent stage thanks to taking a broader perspective of Polish pension reforms.

The paper arrives at the conclusion that subsequent waves of reforms demonstrated immanent flaw which are contradictory goals of the publiclyand privately managed tiers of the system. This paradox of the pension reforms has persisted since 1999 up to present, and seems to explain the policy inconsistency identified above.

\section{Research Methodology}

The analysis of pension engineering and economic reasons for change is organized in historical order. The next section reports in brief what was contemporary re-designing of pension systems at different stages about. The major differences in shape divide the history of pension systems into three periods: pre-reform, the 1990s and beyond as well as 2008 and beyond. This calendar organizes contents of the major section that follows. Objectives of reforming at each stage are derived from announcements of officials who are either politicians or policy-makers or experts. The discussion differentiates between explicit and implicit goals, pointing apart of official announcements also to actual outcomes. 


\section{Changing Design: the Stages ${ }^{1}$}

The most widespread scheme for financing pensions is insurance where a benefit is conditioned on contribution. Apparently, universal old-age insurance is a very special branch of finance as far as its original social mission concerned. The traditional core idea of designing old-age insurance has been safety which is provided by an income (pension) to be paid to a person when at the retirement age; income high enough to protect from living in poverty has been at heart of the mission. The first wave of pension reforms in the 1990s and early 2000s eroded this founding principle in most countries, Poland included.

Originally, the initiative of old-age insurance developed in the private sector, and appeared in form of local mutual insurance (so called social insurance companies in Poland; Bratkowski, 2014). Then it was captured by the state. Under welfare capitalism, universal mandatory pension systems became common; pension-system design in Poland after WWII got the same character. Governments mandated individual employees to participate in the pension systems which were normally publicly managed. Compulsion was considered to generate an implicit government guarantee of decent retirement benefits (minimum pension guarantee). "Decent" refers to levels meeting needs which are believed to be basic for living in the society (so called social minimum). This was a broad meaning of Defined Benefit (DB) formula relating benefit and contribution. Basically, public insurers were believed to afford benefits adequate to social minimum at least due to another founding pillar of pre-reform pension system which was financing on Pay-as-you-go (PAYG) basis since this system of financing allowed for income redistribution.

At the turn of the 1990s and the 2000s as observed in Poland's country category the paradigm of pension systems was changed (Sarfati \& Ghellab, 2012). By saying this, we mean such basic features as ownership characteristics of major fund-managing agents, way of making records ${ }^{2}$, and most of all contribution-to-benefit formula and system of financing.

Firstly, the basic relation between contribution and benefit was changed, namely Defined Benefit (DB) formula was replaced with a Defined Contri-

${ }^{1}$ This section and the next section to some extent draw from my article (Ząbkowicz, 2014). However, their contents have been considerably extended by developments in Poland of the last quarter of 2014 with the scope broadened by funding on voluntary basis. Reforms in full-fledged market economies are left beyond the scope of this paper. For details and variety in design see the article mentioned.

${ }^{2}$ In Poland individual accounting of contributions was introduced in place of a central trust fund. 
bution (DC) formula in the system as a whole. Thus, guarantees of social minimum were withdrawn from the pension industry and the risk of old-age poverty was shifted from managing agent to contributor with extremely low retirement benefit eventually being supplied up to minimal level from social aid resources. According to DB formula, the benefit may be based on the worker's final wage and length of service, however, it does not depend on the amount of assets accumulated in the person's name; instead, funds are adjusted to meet obligations; thus the risk of varying rates of return to pension assets falls on the sponsor. In the traditional system, the fundmanaging public agency was backed by the state budget who was the sponsor. Under DC formula, on the contrary, the benefit is determined by the amount of capital paid in toward a person's pension. A pure DC plan adjusts obligations to match the available funds; thus this is an individual contributor who faces the portfolio risk (Barr \& Diamond, 2008a).

Secondly, with respect to financing the PAYG system was supplemented with capital funded pension schemes. Pay-as-you-go (PAYG) pensions are paid out of current revenue that comes, basically, from contributions to the system made by the actually employed (the prospective pensioners) and/or their employers. Funded pensions use an accumulated fund built from contributions by or on behalf of its members which is invested in securities. In this tier of the system, pension benefits are paid basically from paid-in capital and investment outcomes, and no redistribution between current contributors and current beneficiaries takes place. Thus, a multi-tier system was created. The law of 1997 allowed for pension savings to be channeled to the licensed agents for both voluntary and mandatory funded schemes to be created. The outcome of the reform in the shape of three "pillars" is presented in Table1.

Around 1999, the reform engineering split the traditional pension system into publicly- and privately managed pillars, run by ZUS as well as by the PTEs and TFIs respectively. The PTEs (so called Universal Pension Societies) and the TFIs (so called Pension Funds Societies) in contradiction to ZUS (Public Agency for Social Safety) are private companies founded mainly by banks and some insurers. Thus the state has invited private firms into the area which traditionally was a domain of state compulsion and was managed by a public agency. Mandatory contributions raised by ZUS have since then been divided into funds run by ZUS and run by PTEs, while the funds run by TFIs enjoyed fiscal support in the shape of tax relief. 
Table 1. Old-age insurance in Poland as outcome of the reform of 1999

\begin{tabular}{|c|c|c|c|}
\hline Pillar/tier & I & II & III \\
\hline \multirow{2}{*}{$\begin{array}{l}\text { contribution (as } \\
\text { percentage of wage) }\end{array}$} & 12,22 & $7,30 *$ & as contracted \\
\hline & mandatory & & voluntary \\
\hline \multirow{3}{*}{ funds } & FUS (reformed) & OFE & PPE, IKE,IKZE \\
\hline & $\begin{array}{l}\text { individual accounts, } \\
\text { official valorization }\end{array}$ & $\begin{array}{l}\text { individual accounts, } \\
\text { financial investment } \\
\text { yield }\end{array}$ & $\begin{array}{l}\text { individual ac- } \\
\text { counts, financial } \\
\text { investment yield }\end{array}$ \\
\hline & \multicolumn{3}{|c|}{ Defined Contribution (DC) } \\
\hline management & Public agency - ZUS & $\begin{array}{l}\text { Private companies } \\
\text { PTE }\end{array}$ & $\begin{array}{l}\text { Private companies } \\
\text { TFI }\end{array}$ \\
\hline financing & $\begin{array}{l}\text { Pay-as-you-go } \\
\text { (PAYG) }\end{array}$ & Funded & Fully funded $* *$ \\
\hline \multirow{2}{*}{ Retirement benefits } & ZUS & ZUS*** & \\
\hline & basic & & premium \\
\hline \multicolumn{4}{|c|}{$\begin{array}{l}* \text { The share was reduced to } 3,5 \text { per cent in } 2011 \mathrm{r} \text {. and to } 2,92 \% \text { in } 2013 \text {. } \\
\text { ** Fully-funded pensions pay all of benefits from accumulated funds. Funded pensions use } \\
\text { an accumulated fund built from contributions by or on behalf of its members (Barr, Dia- } \\
\text { mond 2009). } \\
* * * \text { According to the law of } 2013 \text { ZUS is in charge of paying out the annuities from both } \\
\text { pillars. }\end{array}$} \\
\hline
\end{tabular}

Source : developed by the author.

Years 2008 and beyond have seen intense reforming of privately managed sub-system of funded pensions. These developments can be regarded a new stage, in contrast to reforming and splitting traditional PAYG system before. After 2008 numerous regulations referring to OFEs (II pillar) and new propositions referring to voluntary pension funds (III pillar) appeared ${ }^{3}$.

As far as mandatory pension funds concerned, the government scaled them down gradually since $2009^{4}$ with the law of December 2013 as a breakthrough. After 1999, the mandatory contribution used to be automatically divided between pillar I and pillar II (see Table 1), and thus, in effect of state compulsion, open pension funds (the OFEs) were created. Since 2013 the PTEs, that is profit-making companies specialized in managing OFEs, have no longer been sure of steady inflow of contributions. The new law opened an opportunity for members to express their will in multi-years intervals. In defined periods they are allowed to declare whether they are going to stay in the OFE tier vel. pillar II. In the event of no declaration by

${ }^{3}$ Historical report requires mentioning a relevant change introduced in the system as a whole in 2012 that is the shift of statutory retirement age on to 67 to be gradually completed in 2020 with regard to males and in 2040 with regard to females.

${ }^{4}$ There were reductions in fees in 2009 as well as in portions contributed to the OFEs in 2011. 
insured person being made, his or her contribution remains under the management of ZUS, undivided. The same procedure refers to those who are just about to enter the labour market. In the event they have not explicitly chosen otherwise, their contribution will be administered by ZUS since the random selection which used to distribute such cases among the OFEs was cancelled (Ustawa, 2013). The first such opportunity with the deadline for decision-making at end of July 2014 resulted in number of OFEs' members shrinking from ca. 16 million to 2.5 million.

As a result of the 2013 reform OFEs found themselves scaled down not in terms of the number of contributors alone, but also in terms of their share in the mandatory pension saving. Those members who still wish to contribute to an open pension fund can declare only 2,92 of their wage to be transferred to the fund. Thus, both the number of contributors and the value of transfers of individual contributions has shrunk. Consequently, this means a dramatic down-scaling of PTEs' incomes, for which the value of funds accumulated is critical. According to OFE-tier regulations, PTEs benefit from "transaction cost-covering" fees charged as percentage of contribution to OFE and from provisions charged as percentage of funds accumulated. The former was cut by half and reduced to 1,75 p.p., and due to the latter, the revenues fall automatically following the funds.

Independently, that is before the dramatic change in the number of contributors could be included into calculus, in early February 2014 the OFEs found assets on their members' accounts reduced by 51.5 per cent due to obligatory transfer of treasury bonds and publicly guaranteed securities from their portfolios to a special account under ZUS management. The rest of accumulated assets, which is mainly shares, remained with OFEs, no matter whether pension savers declared "stay" either "exit", and is bound to new investment limits. This and a couple of other changes brought into mandatory pension funding by 2013 law will appear in commentary later on. What should be mentioned here is that these assets are going to leak out from the OFEs gradually due to special rule concerning those members who are close to the retirement age. Once a fund-managing company is informed by ZUS that a given OFE-member is aged 10 years below due retirement age it is obliged to default systematically each month a due part of accounting units on his or her individual account, while these liabilities appear on his or her individual account in ZUS (Ustawa, 2013).

Year 2014 witnessed a new offensive with regard to voluntary pension funds. At that time, at the request of President's Bureau, a project was prepared by the Association of Polish Economists, and was officially presented in January 2015. Its general idea seems to be accommodating voluntary schemes by transfers of public money, as well as providing new members 
due to introducing by the state a peculiar automatism beside individual choice. The expertise suggests three options which are tax relief for the IKZE- and IKE-members, a quota of public money for prospective contributors, and universal automatic participation in PPE with opportunity to optout. The first and the second option are so designed as to expand TFI customers group including the people who earn wages below the average in particular. This is to be achieved thanks to giving-up a part of budget revenues due to personal income tax (PIT) and/or via public donations to individual accounts run by the TFIs. The costs for state budget are estimated in the report at milliards of zlotys, varying from 2.2 milliard to 6.2 milliard per year for a single case (Dodatkowy..., 2014).

The third option of pension saving with the TFIs are employers pension schemes (PPEs) already in operation, however, with the reversed act of will of the insured persons as a novelty. Presently, a declaration of an employee is necessary to participate in the scheme. According to the new design, a declaration of an employee would be necessary in aim to opt out, since under the regulations proposed each employee and each newly-employed person would automatically become a member of a PPE chosen by the company. The project is a promise of rapid increase in number of contributors for TFIs and of an almost costless arrangement for employers. The latter is based on the idea that employer's part of contribution could be paid from company's social funds (ZFSS). The experts estimate these funds at ca 2 milliard zloty per year (Dodatkowy..., 2014). Thus, this option, instead of the public money, makes company's social funds engaged and transferred in part to pension funds.

Summing up, the year 2014 saw dramatic cuts in funds transferred to pillar II by public agency (ZUS) on the one hand, and projects to transfer considerable amounts of public and/or social money to pillar III on the other hand. This policy inconsistency needs deliberation. For better understanding of the processes observed, one must take a perspective which is broader than pension engineering, and has to trace the objectives of reforming pensions, which definitely can not be reduced to the traditional social mission.

Doing so, we will draw from/take advantage of this piece of analysis. This section has shown that dynamics of reforms in Poland can be measured by stages as reported above.

- The starting point is the pre-reform shape of the pension system. Mandatory pension saving was managed exclusively by a public agency then, with implicit state guarantees of retirement benefits adequate to social minimum. 
- Years 1999 and beyond saw the architecture of pension system profoundly transformed, due to shifting the risk of old-age poverty from managing agency to contributors in the system as a whole, with privately managed pension funding having been introduced.

- Years 2008 and beyond, and 2013 in particular, brought relevant reforms of privately managed pension funding with mandatory pension saving getting scaled down, and with voluntary pension saving becoming eventually accommodated by transfers of public money and/or provided by new members to extraordinary extent.

The search for explicit and implicit objectives of change will be organized in accordance to these stages.

\section{Changing Design: Objectives and Outcomes}

Contemporary rhetoric concerning goals of pension reform says about improved social safety, fiscal balance and solvency of the pension system, individualism and privatisation. Such rationalization is still present in political and economic debates. Actually, historical approach to dynamics of reforms reveals a departure from functions of mostly social and political nature to accounting and other issues related with private and/or public finance.

\section{Pre-reform}

The pension system as designed in Poland at pre-1999 stage can be said to have had counter-poverty and counter-social-exclusion functions. According to Barr and Diamond (2014, p. 31), there are two basic functions of the pension system. Pension funds are designed to "smooth down" the income along lifetime of an individual that is while employed and while retired. In social dimension pension-system function is also to redistribute income and wealth in aim to contain poverty of contributors after retirement. Obviously enough these functions declared by Barr and Diamond as their focus aim at economic safety and material-needs satisfaction of the pensioners. However, they are by no means entirely economic objectives, but rather social and/or political ones. National pension systems had been designed with regard to improving social equity and thus preserving social peace.

The latter statements are supported by Polish pre-reform evidence. The heritage of the previous social and economic order was the pension system 
where one of the construction pillars was PAYG financing and income redistribution, and another was DB formula with state implicit guarantees regarding social minimum. The opening years of systemic transformation in Poland saw social peace broken and pension system used as a device of cooling down social riots. Those appeared mostly as going on strikes in great state-owned enterprises, where both real wages and jobs seemed to be affected by macroeconomic austerity and the set-off of privatisation. As a matter of fact, unemployment rate was on dramatic rise, and with the goal to reduce social and political costs of mass unemployment in mind, early retirement was allowed, as well as invalid rents became relatively easy to acquire. Thus, increased outlays from the pension system replaced to a large extent social aid, and a number of people acquired status of early pensioners and official invalids instead of being unemployed. In the 1990s the publicly managed system of old-age insurance was used more apparently than ever to serve social and political goals 5 .

This early re-forming of the system, however, increased implicit pension debt to unprecedented extent ${ }^{6}$. One decade later, at the turn of the millennia, pensions and rents were paid out to nearly 25 per cent of inhabitants, while people at the retirement age constituted only 13 per cent (Zieliński, 2003). Increased outlays contributed to public finance instability, current illiquidity and implicit insolvency of the pension system. At the turn of 1999 and 2000 the statistics for Poland revealed significant pension spending and record implicit pension debt (Impavido \& Tower, 2009, p. 41). The latter is meant by the IMF as a rough indicator of the accrued value of the pension system liabilities where the government needs to bail out the pension system. According to the IMF, among thirty five low and middle income countries Poland had 3-rd largest pension spending as share of GDP and 5-th largest implicit pension debt as share of GDP with public debt at that time being though relatively moderate (the 16-th position).

\section{9 and beyond}

Improving the deficit of the public pension (and implicit pension debt) became an urgent objective of the 1999 reform. The related issue was constraining the increase in the public debt. Although the public debt was ra-

\footnotetext{
${ }^{5}$ Moreover, some professions of political relevance like police, army, judges, clergymen have enjoyed noncontributory universal pension financed from the governmental budget.

${ }^{6}$ Other reason of implicit pension debt more widely publicized than that one was demographic change. While considering this argument to be rather controversial when applied to Poland we deliberately skip the discussion for the sake of maintaining line of reasoned discussion.
} 
ther moderate when 1999 reform gained shape, it could be easily predicted to be on rise, since the public pension was in deficit. As already said, the DB formula means funds are adjusted to meet obligations, and when public pension system is unable to make this adjustment, then implicit benefit guarantees make the state to become the sponsor. Thus outlays from the state budget on behalf of public pension appear and, eventually, budget deficits increase. Under such circumstances, shifting from DB to DC means a relief to the budget. With the portfolio risk shifted to individual contributor, there was a relief to the sponsor. Therefore, the change in the formula in 1999 should be seen as aimed indirectly at prospective problem of public debt.

Improving implicit pension debt can be regarded to be a goal while constraining rates of replacement to be an immediate objective. Naturally enough, when a public pension is running a deficit that is regarded as unsustainable, a way is to make it sustainable is increasing contributions, reducing benefits, or both (Barr \& Diamond, 2008b). In Poland, the relative benefit was radically reduced, which means plummeting of the predicted pension benefit as related to the average or the last wage (Wiktorow, 2008, p. 36). In pension-engineering slang this index is called a rate of replacement. The diminishing values of the index meant roughly that planned outflows from the system were to be lower in relation to inflows to the system, and this was the way of constraining rise in the implicit pension $\operatorname{debt}^{7}$. One of the authors of the reform claimed in 2002: "The reform apparently was just aimed at diminishing this index. In the ageing society this is a requirement of systemic solvency." (Hausner, 2002).

Thus, the fundamental change in the contribution-to-benefit formula appears to serve a relief in public finance or, to be more precise, in generalgovernment finance ${ }^{8}$. This means that accounting and financial goals won priority over social ones. The same observation can be applied in the case of another fundamental change in design concerned, which was the emergence of pension funding. Investing part of savings accumulated in pension funds instead of paying them out immediately for pensions and current consumption, as it used to be under the PAYG-system actually means introducing financial logic into the system. Pension funding, however, was never chosen to be presented to the public in that direct way.

The foreseen constraint in rates of replacement needed to be somehow cushioned with regard to the public. The official concept of "security due to

${ }^{7}$ Another way of reducing outflows from the system and postponing them as well was shifting a retirement age. It became politically feasible, however, only in 2012.

${ }^{8}$ General government contains, beside the governmental budget also local budgets and other (extra-budgetary) public funds. 
diversity" which was originally elaborated by UNFE (2000) said that a multi-tier system is to create more security for prospective pensioners. Including pension funding into the reform seemed to be of help along with the following rationale attached. Funded pension schemes will possibly increase their part of pension income, improve the sum of benefits originating from different pillars and effectively constrain a further risk of old-age poverty. This reasoning makes a multi-pillar approach for the pension system attractive thanks to suggestion of improving rather than deteriorating outcome of the system as a whole. Another argument extensively used said that funding in the pension system made pensions free from political abuse ("political risk"), to some extent at least.

The rhetoric pointing to social function of institutional design with pension funds constituting additional pillars provided a smokescreen. The point is that pension funding, and OFE in particular, was introduced not to secure future pensions, but to invest pension savings (Szumlicz, 2002). As far as mandatory pension funding concerned expertise for decision-makers exposed saving-and-investment issues. It said about "profit-oriented investment regarding acceptable risk" being rather enigmatic on possible increase in retirement benefits (Grabczan, 1998). The supporters of introducing the OFEs added "fairness" of the deal (Góra, 2002) which is, however, a double-edged sword with respect to benefits, since capital pension funding is subject evenly to losses and gains under bessa and hossa, and no insurance for mandated contributors against the loss of assets was introduced.

As a matter of fact, new pension system architecture introduced financial-market logic to where principle of social insurance had ruled. Financial markets development can be said another genuine goal of the 1999 reform. Pension funds channel domestic savings to financial operations being a vehicle of exchange of their contributors' savings into securities, so their rise meant an increase in turnover of bonds and shares by definition. Moreover, new opportunities of making profits on financial-assets turnover have attracted foreign capital. We find expansion of pension funding by financial intermediaries and, consequently, financial markets development as another major goal beside relief to public finance.

To sum up, of the two major changes which the reform brought, the shift from DB to DC formula was a rather direct device of alleviating the pressure on the pension and budget deficits. The shift from DB to DC means as already said that funds which can be found at the core of contemporary pension systems are to be adjusted to meet obligations no more. Thus, public pension deficit can be constrained and subsidies from the state budget can be diminished. This is the non-questioned financial aspect associated with the Polish reform that is ultimately beneficial for public finance 
(Łaski, 2010). Another shift, however, namely the move to mandatory funding had an immediate adverse effect on both public pension and budget deficits. The price to be paid was the explicit budget gap due to transferring to OFEs "their" portion of contribution which increased deficits of the publicly managed pension fund (FUS) and enforced donations from the government budget thus contributing to fiscal deficits. Three concepts at least served to cut controversy about the move to mandatory funding from the fiscal point of view. They were privatization funds as a cushion; supposition that the OFEs would be included into general government, with the EU approval; the premise that developed financial markets are good for economic growth. From retrospect, all of them turned out to be weaklyfounded. The fiscal cost of voluntary funding, mostly due to tax relief, can be neglected as far as now, because of marginal size of this tier, however, it is potentially detrimental along with increasing both the size of the pillar and the scope of privileges of this tier.

Introducing funding into the Polish pension system, however detrimental from fiscal perspective, was relevant for financial markets development. A part of mandatory pension savings is transferred out beyond the PAYG system, and is bound to market rules. Transferring a portion of pension savings, voluntary savings included, to financial markets results in increases in securities turnover, and means a development of earning opportunities there. As a matter of fact, the OFE project and introducing voluntary pension funding as well, were an invitation for foreign capital groups to bring equity and go into business in Poland in the shape of the PTEs or TFIs. In 1999 foreign investors held, directly or indirectly 75, per cent of the PTEs assets (Rymsza, 2002, p. 265). The biggest open pension funds got under the management of international banks and insurers or their subsidiaries, with ING Nationale-Nederlanden Polska, Unicredit and AIG among them. Under transition to full-fledged market economy, the development of financial markets as well as rules inviting for foreign capital inflows apparently gained in prominence. At the turn of the millennium particularly OFEs could have been perceived as a helpful institutional device in these respects. However, such speculations, if in place, turned out to be exaggerated, and explicit public debt issue became a first-hand reason for 2013 policy turnabout.

\section{3 aftermath}

Transfers of percentage of mandatory contributions to OFEs mentioned before, which had added to fiscal deficits and, consequently, to public debt appear as the main reason of the reversal. According to the stance, con- 
firmed definitely by Eurostat in 2004, OFEs can not be regarded as an institution of general government sector. If so, transfers made by ZUS to OFEs count as liabilities of the sector and add to public debt as related to GDP a couple of percentage points. After having broken the EU budget deficit bench-mark, with the burden of public debt approaching another EU limit, the government represented by minister of finance John Vincent Rostowski said the cost of maintaining OFEs in terms of public debt was too high. Thus, even more obviously than in the late 1990s, the reform in 2013 was induced by General Government accounting. The law of 2013 was explicitly aimed at constraint of costs which the pension system meant to the governmental budget, and predicted numerous economic benefits due to that action (Uzasadnienie..., 2013, pp. 61-62).

However, one can argue that in spite of determination in following the fiscal line even after 2013, some other regulations were oriented towards the expansion of private pension funding. There are two arguments, at least, which seem to support such an implicit goal. Firstly, OFEs have never been eradicated, and we are going to show now that they can still prosper fairly well after 2013. Secondly, we are just observing a changing attitude on behalf of the voluntary funded pillar. The ideas which founded the PTEs' business seem to find continuation in projects concerning the TFIs.

The reform of 2013 keeps mandatory pension funding still active. As already said, it has opened the opportunity to shift membership out of the OFE tier and reduced significantly the assets at OFEs' disposal. Thus, the logics of doing business by the PTEs (and probably, their involvement as well) must have been changed. They are to rely less on the amount of capital and due fees, and they will probably strive for rewards based on the velocity of capital turnover. This supposition seems to be in accord with some other regulations introduced by the law of 2013. The fees charged as a percentage of contribution were radically constrained, and thus the due revenues were reduced ${ }^{9}$. However, since 2014 , the structural limits concerning OFEs' assets have been abolished, and the maximum share of assets denominated in foreign currencies was impressively increased from 1.27 per cent to 30 per cent (Uzasadnienie..., 2013). This opens space for relatively risky operations on shares, and in foreign stock exchanges in search of higher yields. Moreover, each PTE is free to point reference indices of their own to be used as a benchmark to the rates of return of "their" OFE (Rutecka, 2014). With equities share in assets increased up to 85 per cent mandatory pension funds are likely to turn into aggressive investment

${ }^{9}$ As far as other factors of calculus concerned the maximum management commission charged by the PTEs on assets remained unchanged and fees paid due to transfers made by ZUS were cut down to $0,4 \%$. 
funds. The OFEs saw their assets, both those accumulated and those predicted, significantly reduced, and the PTEs probably have to accept their record rates of return plummeting (Capital Strategy, 2013). Nevertheless, simultaneously, new opportunities of doing business in the mandatory funding tier appeared. Therefore, the reform must be seen as a struggle to constrain public deficits and debts, rather than a battle against privileges in the mandatory privately managed tier. The OFEs have been not eradicated, and fund-managing companies still have a chance to be handsomely rewarded, provided they become far more aggressive investors in the capital markets.

As far as pension schemes managed by the TFIs concerned an idea of universality is on top, as expressed explicitly in the motto of the 2014 project and repeated in the declared objectives of three proposals discussed above in section 2 of this article. Pension funding in pillar III is meant to acquire a universal dimension in the sense of mass membership, the pre2013 pillar II alike. Respectively, thanks to a tax relief "as many people as possible" from low-income groups are to be included into the IKE and IKZE schemes, which are to be attractive for both full-time workers and the self-employed as well (Dodatkowy...., 2014, p. 57). This is also the target group of the second proposal referring to the public donation for individuals as a "carrot" which would result in "universal individual extra old-age insurance" (Dodatkowy...., 2014, p. 65). Similarly, the last proposal aims at "universal participation in employers' schemes" (Dodatkowy...., 2014, p. 70). This option is most likely to result in mass membership due to automatic inclusion of persons employed in the public and private sectors. This "automatism" would be achieved thanks to respective change in law. Therefore it can be regarded as a "stick" or a discreet introduction of state compulsion into III pillar (Oręziak, 2015). Opting-out, which would be allowed in strictly defined periods of time, seems to be far not enough to call this form of insurance a voluntary one. The explicit goal of the projected reform is to make membership to pension funding run by the TFIs as large as once the membership to pension funding run by the OFEs used to be; the implicit intermediate objective with regard to this option is to change its voluntary nature into mandatory saving, thus in fact following the OFE pattern again.

The claim on expansion of privately managed pension funding may appear paradoxical in the face of down-scaling the OFEs under the law of 2013. However, this law makes the PTEs free to be more aggressive investors in capital markets, and thus new opportunities of doing business and money have been given to them. Moreover, the first year under new law concerning OFEs saw a change in thinking in favor of funds managed by TFIs. The project of 2014 just discussed may be regarded as an attempt to 
compensate the dramatic down-scaling of mandatory pension funds with channeling savings to voluntary pension funds, even if it was to be made with use of "stick".

Putting findings in this section together:

- The pre-reform pension system had been oriented at functions of mostly social and political nature.

- The 1999 reform initiated a departure to accounting issues related with private and/or public finance. The socially-sensitive pre-1999 system was split into three parts, with pension funding in pillars II and III, governed by principles definitely different from counter-poverty and counter-exclusion functions. Improving the deficit of the public pension (and implicit pension debt), and developing capital market with the help of pension funds more accurately describe objectives of this reform.

- The explicit objective of 2013-turnabout was of accounting and financial nature as well. The reformers' endeavors have been aimed at cutting systemic costs for the sake of reduction in the budget deficits and public debt on the one hand and at revitalization of privately managed pension funding on the other hand.

\section{Conclusions}

Historical approach reveals a departure of the Polish pension-system design from the functions of mostly social and political nature to goals related with private and/or public finance. Since 1999 the reforms seem to constitute two interlocking streams of change aimed at i) relief to public finance ii) expansion of pension funding and financial market development.

Under new demographic, economic and political circumstances, publicly managed system of mandatory pension saving was said to be implicitly insolvent. Political consciousness of this development induced reforms in the 1990s that were believed to constrain the financial consequences of state implicit guarantees and, thus, public pension debt. This was achieved by shifting from DB- to DC-formula, which did not, however, improve the situation in the general government sector. Introducing pension funding and privatization of the pension industry was of help in the sense of dispersing the responsibility for diminishing rate of replacement. However, mandatory funding is controversial from the perspective of the general government finance, due to the transfers of a percentage of contribution raised by the ZUS public agency away to OFEs. In spite of this structural flaw, which actually compelled the state budget to provide donations to ZUS, mandatory pension funding was introduced and maintained. 
Although pension funds are neither solution to the implicit insolvency problem nor source of fiscal relief (Chełchowski, 2001) this institutional arrangement has found support at every stage of contemporary pension reforms in Poland. Taking this under consideration, introducing and expansion of pension funding can be seen as an end in itself, which is tightly related to financial market development. As a matter of fact, the OFE project, as well as pension funding on voluntary basis, meant inviting foreign capital to the emerging market economy of Poland. The last paragraphs of the previous section provide arguments that this finding remains valid, however impressed we could be by recent radical change concerning OFEs.

The two goals, however, are in contradiction to each other, and this makes a paradox of pension reforming in Poland. On the one hand, there is a strain to improve public finance. On the other hand, expansion of pension funding by private agents requires allowing real tax money and contributions to outflow from general government sector to the privately managed tiers.

The analysis that has helped us to identify the two contradictory policy objectives makes the picture of recent reforming more clear. There is some logical line in recent thinking on the pension funding in pillar II and pillar III in Poland. The OFEs became a victim of reforming along fiscal lines for the sake of relief to the public finances. The Rostowski's reforms were a blow against expansion of pension funding and financial markets, due to down-scaling of the OFEs. However, the review of 2013- and 2014- design resulted in conclusion that at present reforming is focused on revitalization of pension funds. It was argued that both some 2013 regulations and the 2014 project as a whole constitute, to some extent, the compensation and act in favour of financial market development, with new opportunities of doing business given to OFEs and mass membership in funded voluntary pension plans being projected. The recent focus on pension funding may make distress in public finance recurrent. Are the contemporary pension reforms more about expansion of the financial sector than anything else then?

\section{References}

Barr, N., \& Diamond, P. (2009). Reforming Pensions. CESifo Working Paper, No. 2523, January. DOI: http://dx.doi.org/10.1093/acprof:oso/9780195311303. 001.0001.

Barr, N., \& Diamond, P. (2014). Reformy systemu emerytalnego. Krótki przewodnik. Warszawa: PTE. 
Barr, N., \& Diamond, P. (2008b). Reforming Pensions: Principles and Policy Choices. New York: Oxford University Press.

Barr, N., \& Diamond, P. (2008a). Reforming Pensions. ISSR Draft November 2008. Retrieved from http://econ.lse.ac.uk/staff/nb/Barr_Diamond_crr.pdf (13.03.2015)

Bratkowski, S. (2014). Emeryt na łasce hazardu. Gazeta Wyborcza, 1-2nd February

Capital Strategy (2013). Wpływ OFE na rynek kapitałowy i rozwój gospodarki, 26.06.2013. Retrieved from http://www.efcongress.com/sites/default/files/kawa lec-przezentacja_dla_ekf_-_2013-06-26.pdf (13.09.2013).

Chełchowski, A. (2001). Strategie inwestycyjne funduszy emerytalnych - reforma emerytalna - sukces czy porażka. BRE Bank/CASE Working Paper, No 57; Retrieved from http://www.nbportal.pl/library/pub_auto_B_0001/KAT_B215 0.PDF (17.06.2014).

Dodatkowy system emerytalny w Polsce - diagnoza i rekomendacje zmian (2014). Warszawa: Towarzystwo Ekonomistów Polskich

Grabczan, W. (1998). System otwartych funduszy emerytalnych jako element nowego systemu zabezpieczenia społecznego. Biuro Studiów i Ekspertyz, Informacja $\mathrm{nr}$ 642. Retrieved from http://biurose.sejm.gov.pl/teksty/i-642.htm (17.07.2014).

Góra, M. (2002). Emerytury - fakty i mity. Rzeczpospolita, 2nd April

Hausner, J. (2002). Rzeczpospolita, 27th February

Impavido, G., \& Tower, I. (2009). How the Financial Crisis Affects Pensions and Insurance and Why the Impacts Matter. IMF Working Paper, 9/151, July.

Łaski, K. (2010). Mity i rzeczywistość w ekonomii. Biuletyn PTE, 1.

Oręziak, L. (2015). Druga pułapka OFE. Przegląd, 9-15.02.

Rymsza, M. (2002). Ubezpieczenie emerytalne w zreformowanym systemie ubezpieczeń społecznych w Polsce. In T. Kowalik (Ed.). Nierówni i równiejsi. Sprawiedliwość dystrybucyjna czasu transformacji w Polsce. Warszawa: Fundacja Innowacja.

Rutecka, J. (2014). System emerytalny po zmianach od 2014 roku. Teoria i praktyka ubezpieczeń w Polsce, 1(118).

Sarfati, H., \& Ghellab, Y. (2012). The Political Economy of Pension Reforms in Times of Global Crisis: State Unilateralism or Social Dialogue? Working Paper ILO, No. 37, February

Szumlicz, T. (2002). System zabezpieczenia emerytalnego. In A. Kurzynowski (Ed.). Polityka społeczna. Warszawa: Instytut Gospodarstwa Społecznego SGH

UNFE (Urząd Nadzoru nad Funduszami Emerytalnymi) (2000). Bezpieczeństwo dzięki konkurencji. Warszawa.

Ustawa z dn. 6 grudnia 2013 o zmianie niektórych ustaw w związku z określeniem zasad wypłaty emerytur ze środków zgromadzonych w otwartych funduszach emerytalnych (dz.U. 31 grudnia 2013 poz.1717).

Uzasadnienie zmian w systemie ubezpieczeń społecznych z dn. 10.10.2013, Retrieved from http://www.mpips.gov.pl/aktualnosci-wszystkie/ubezpieczeniaspoleczne/art,6408,startuja-konsultacje-spoleczne-reformy-ofe.html $(31.05 .2014)$ 


\section{Anna Ząbkowicz}

Wiktorow, A. (2008). Ryzyko załamania systemu ubezpieczeń społecznych. Zarzadzanie ryzykiem, 28.

Zieliński, M. (2003). Zawód emeryt. Wprost 29th June.

Ząbkowicz, A. (2014). Institutional Interests and Institutional Change. Poland on the Second Wave of Pension Reforms. Equilibrium. Quarterly Journal of Economics and Economic Policy, 9(3). DOI: http://dx.doi.org/10.12775/ EQUIL.2014.024. 